UDC 57.08:636:31

\title{
IMPACT OF CRYOPRESERVATION ON LIPID COMPOSITION OF SPERM CELLS OF MALE STERLETS (ACIPENSER RUTHENUS L.)
}

\author{
L. P. Drahan ${ }^{1}$, S. P. Veselsky ${ }^{2}$, Yu. P. Rud ${ }^{1}$, L. P. Buchatsky ${ }^{1,2}$ \\ ${ }^{1}$ Institute of Fisheries, NAAS, 135, Obukhivska Str., Kyiv, Ukraine 03164 \\ ${ }^{2}$ Taras Shevchenko National University of Kyiv, \\ 60, Volodymyrska Str., Kyiv, Ukraine, 01033 \\ e-mail:dragan_l@ukr.net,
}

Received on January 31, 2018

\begin{abstract}
Aim. To investigate the impact of low temperatures on the lipid composition of reproductive cells of male sterlets (Acipenser ruthenus L.) in a deep-freezing environment. Methods. The determination of sperm quality (color, consistence, concentration, and motility of spermatozoa) was estimated by common biochemical methods and light microscopy using standard equipment. Thin-layer chromatography was used to reveal five fractions of neutral lipids in the sperm of sterlet (Acipenser ruthenus L.) from three different river regions viz. Danube, Dnipro, and Volga. All lipid fractions (phospholipids, cholesterol, free fatty acids, triacylglycerol and ethers of cholesterol) showed a mean lower percentage (70, 12, 10, 5 and $3 \%$, respectively) for the three sterlet populations. Motility was also severely impaired (with a mean c. $50 \%$ ). Results. The impact of low temperatures on the lipid composition of reproductive cells of male sterlets (Acipenser ruthenus L.) in a deepfreezing environment leads to substantial changes therein. Conclusions. The impact of low temperatures on the lipid composition of reproductive cells of male sterlets (Acipenser ruthenus L) in cryopreservation environment leads to impairments of the phospholipid bilayer of their membranes. It was established that during the thawing of frozen sperm cells which preserved their viability after cryopreservation their motility and capability of fertilizing an ovum were somewhat restored with slowing down of sperm cell motility.
\end{abstract}

Keywords: lipids, cryoprotecting environment, cryobank.

DOI: $10.15407 /$ agrisp5.01.075

\section{INTRODUCTION}

One of the most urgent issues of fisheries in Ukraine is enhancing the efficiency of restoring populations of aborigine, unique, endangered and economically valuable species of fish. In order to achieve this, there is a definite need of full scale growing of these species under artificial conditions and the development of aquaculture as an agro-industrial sector using low-cost and efficient technologies. A popular trend to improve and increase or save gene pools of fish populations is artificial fertilization. One of the decisive factors in the efficiency of artificial fertilization is improving the methods of long-term preservation of fish sperm at low temperatures (cryopreservation).

(C) L. P. DRAHAN, S. P. VESELSKY, YU. P. RUD, L. P. BUCHATSKY, 2018
Moreover, the presence of genetically representative collections of fish genomes from female populations in sturgeon fish-breeding complexes from natural populations in a cryobank ensures the preservation of genetic biodiversity of these species for the environment and industry.

The technology of preserving and using the frozen sperm of rare and endangered fish has long been worked out $[1,2]$. But many of its negative impacts on sperm have not been fully overcome yet. Freezing without cryoprotectant compounds added to the freezing medium causes considerable structural and biological defects of sperm cells. These defects lead to the impairment of permeability of plasmatic membranes and the release of some enzymes and other relevant metabolites of cellular exchange from sperm cells with an often considerable decrease in fertility of sperm [3]. 


\section{DRAHAN et al.}

The efficiency of the technology of cryopreserving sperm of male sterlets and its impact on the lipid composition of this sperm is presently not well known.

Our study tries to fill this gap, possibly allowing determination of new ways to enhance the viability and biological full-value of sterlet sperm cells during shortand long-term storage in deep-frozen state.

\section{MATERIALS AND METHODS}

The samples originated from the sperm of sterlet (Acipenser ruthenus L.), obtained from Danube, Dnipro, and Volga populations during the spawning campaign.

Ten samples were taken from each river population, deep-frozen and studied at the specialized fishery of Vilkove, Odesa Sturgeon Complex LLC and the Biotechnology laboratory of the Institute of Fisheries, NAAS.

Sperm quality was determined visually using a light microscope Biolam D-13 (Russia). Sperm appearance (color, consistency) was determined as well as its concentration using Goryaev's chamber (equivalent of a haemacytometer), and their lifetime using a stop-watch.

Freezing/thawing of sterlet sperm samples was conducted by the methods, commonly used in cryobiology [4]. Cryopreservation and defrosting of sperm was conducted in glass ampules according to the method, described by Lunev in 2009 [5], using methyl alcohol instead of the traditional dimethyl sulfoxide. This method was implemented via diluting $(1: 1)$ the sperm prior to freezing with a cryoprotecting solution, containing saccharose $14.6 \mathrm{mM}$, potassium chloride 13.4 $\mathrm{mM}$, and methanol $3.73 \mathrm{M}$ with subsequent liquid nitrogen vapor freezing. The diluted sperm was frozen in two stages: the first one - from $5{ }^{\circ} \mathrm{C}$ till $-15^{\circ} \mathrm{C}$ with the rate of $2-3{ }^{\circ} \mathrm{C} \mathrm{min}-1$; the second one $-15-70$ ${ }^{\circ} \mathrm{C}$ with the rate of $15 \div 20{ }^{\circ} \mathrm{C}$ min- 1 , with subsequent slow submerging into nitrogen till $196{ }^{\circ} \mathrm{C}$. Changes in temperature in the samples were registered by a chromel-copel thermocouple using the multimeter EC890G (MAXTECH company, Canada) with $0.2{ }^{\circ} \mathrm{C}$ precision. To thaw the ampules, the latter were transferred to a water bath kept at $38-40{ }^{\circ} \mathrm{C}$, stirring the water constantly to enhance heat exchange until the liquid phase and controlling the temperature in the thawed samples to be in the range of $18-23{ }^{\circ} \mathrm{C}$. The thawed sperm was activated with pond water. The preservation of sperm was checked in each sample at least three times with the determination of mean values. Motility of sperm cells at different stages during the preservation process was determined visually with 20 -fold magnification. Total lipids in the ejaculate were separated by micro-thin-layer chromatography. The lipids from sterlet ejaculate were extracted with a chloroform-methanol mixture $(2: 1)$. The separation of lipids into fractions was performed on the plates with a thin silica gel layer (LS 5/40, Czech Republic) in the following system of solvents : hexane: diethyl ether : glacial acetic acid $(85: 15: 1)$. Chromatograms of specific fractions of lipids were developed in iodine vapor using the method of Maksymenko [6]. Lipid extraction was performed by the method of Folch [7]. Protein concentration was determined according to the Lowry method [8]. The adaptive capacity of sperm was estimated via determination of the percentage of spermatozoa survival immediately prior to and after cryopreservation [9]. Statistical analysis was performed using Student's t-criterion and the package of applications for processing medical and biological information - Statistica 6.0 (StatSoft, Inc., USA) for Windows [10].

\section{RESULTS AND DISCUSSION}

The obtained results of sterlet sperm activity prior to and after cryopreservation demonstrate high quality of native sperm and its considerable (up to

Table 1. Characteristics of sterlet sperm (Acipenser ruthenus L.) prior to and after cryopreservation $(M \pm m, n=5)$

\begin{tabular}{l|c|c|c|c|c}
\hline \multirow{2}{*}{$\begin{array}{c}\text { Sterlet } \\
\text { populations }\end{array}$} & $\begin{array}{c}\text { Sperm } \\
\text { concentration } \\
\mathrm{mln} / \mathrm{mm}^{3}\end{array}$ & $\begin{array}{c}\text { Duration } \\
\text { of motility of } \\
\text { native sperm } \\
\text { cells, min }\end{array}$ & $\begin{array}{c}\text { Duration } \\
\text { of motility of } \\
\text { thawed sperm } \\
\text { cells, min }\end{array}$ & $\begin{array}{c}\text { Percentage of sperm cells, preserving } \\
\text { their motility before and after freezing } \\
\text { in liquid with cryoprotectants, \% }\end{array}$ \\
\cline { 4 - 6 } Danube & $0.93 \pm 0.018$ & $8-10$ & $4-6$ & $98-100$ & native \\
Dnipro & $0.74 \pm 0.026$ & $5-7$ & $2-5$ & $99-100$ & $53-55$ \\
Volga & $0.99 \pm 0.023$ & $7-10$ & $3-6$ & $99-100$ & $58-51$ \\
\hline
\end{tabular}

$\mathrm{P} \leq 0.05 ;(M \pm m, n=5)$ from each population. 


\section{IMPACT OF CRYOPRESERVATION ON LIPID COMPOSITION OF REPRODUCTIVE CELLS}

$50 \%$ deterioration after freezing/thawing, even with a cryoprotectant added (Table 1).

The number of mobile gametes after thawing decreased to 54, 48 and $56 \%$ respectively. The fact that the decrease was not more that $60 \%$ may be explained by the presence of a cryoprtectant such as methanol, in our freezing medium $[11,12]$. The mechanisms of energy exchange regulation are known for their highest sensitivity to cooling and freezing/thawing sperm. Such experimental manipulations with sperm cells of animals lead to changes in the organization and integrity of membranes of plasmatic and acrosomal membranes, the release of enzymes from cells, damage to membrane structures of mitochondria and impairing the functioning of the respiration chain - separating respiration and phosphorylation and increasing the production of damaging free oxygen radicals $[13,14]$.

Structural defects of the membrane may serve as a target point for many agents - osmotic forces, lyotropic ions, catalysts, toxins, temperature and other factors, leading to secondary biochemical changes [13]. Therefore, the following stage in our research was to determine the lipid composition of sperm of sterlet from Danube, Dnipro, and Volga populations before and after freezing.

In our micro-thin-layer chromatography the following five fractions were recovered and visualized: phospholipids, cholesterol, free fatty acids, triacylglycerol and ethers of cholesterol. These compounds are the main structural elements of biological membranes, determining the main physical, chemical and functional characteristics of membranes of sperm cells [17].

The lipid profile of native sperm of different populations of sterlet (Danube, Dnipro, and Volga populations) did not show qualitative differences, except for the content of cholesterol and its ethers in sterlet from the Dnipro population.

Our study shows that there were impairments of the phospholipid bilayer of sperm membranes during freezing/thawing. Phospholipids decreased to $34 \%$ in sterlet of the Danube population, to $35 \%$ in those of the Dnipro population, and to $49 \%$ in those of the Volga population as compared to their native sperm (Table 2).

The main factor, controlling the fluidity and permeability of the cellular membrane, is cholesterol. When the content of cholesterol is increased, the bilayer of lipids becomes less fluidal on the external surfaces and more fluidal on the internal, hydrophobic layer. It regulates the permeability of cellular membranes, dependent on temperature, and is capable of partial removal of the membrane-destabilizing action of lipids in the cooling process [18]. As the ratio of cholesterol and phospholipids in the sperm cells of fish is low and cholesterol is asymmetrically located, it is more present in the external layer of the membrane than in the internal one. Therefore, the internal layer of lipids is rather labile to cold shock $[11,19]$.

Our experiment showed that the content of cholesterol decreased from 59.6, 32.1 and $70.4 \mathrm{mg} / 100 \mathrm{ml}$ in the native ejaculate to 23,11 , and $33 \%$ for frozen sperm cells of the Danube, Dnipro, and Volga populations respectively (Table 2).

It is known that cholesterol and phospholipids, as structural components of biomembranes, form complexes of different stoichiometry in them, and the ratio of cholesterol and phospholipids (Gyorgyi's coefficient) is one of the main indices for the degree of viscosity (fluidity) or rigidity of biological membranes $[13,14]$. Gyorgyi's coefficient in the sperm of Danube and Volga sterlet was 0.14 and in Dnipro sterlet it was

Table 2. The content of total lipids in sterlet sperm (Acipenser ruthenus L.) prior to and after cryopreservation

\begin{tabular}{l|c|c|c|c|c|c}
\hline \multirow{2}{*}{$\begin{array}{c}\text { Indices, mg/100 ml } \\
\text { of ejaculate }\end{array}$} & \multicolumn{2}{|c|}{ Danube sterlet } & \multicolumn{2}{c|}{ Dnipro sterlet } & \multicolumn{3}{c}{ Volga sterlet } \\
\cline { 2 - 7 } & native & cryopreserved & native & cryopreserved & native & cryopreserved \\
\hline Phospholipids & $272.0 \pm 0.09$ & $179.6 \pm 1.28$ & $181.9 \pm 0.06$ & $117.7 \pm 0.008$ & $288.2 \pm 0.07$ & $148.0 \pm 0.95$ \\
Cholesterol & $59.6 \pm 0.04$ & $25.9 \pm 0.05$ & $32.1 \pm 0.003$ & $29.0 \pm 0.005$ & $70.4 \pm 0.005$ & $20.9 \pm 0.03$ \\
Free fatty acids & $33.1 \pm 0.02$ & $29.9 \pm 0.07$ & $39.9 \pm 0.005$ & $27.4 \pm 0.007$ & $36.2 \pm 0.003$ & $14.6 \pm 0.02$ \\
Tryacylglycerol & $17.3 \pm 0.07$ & $13.7 \pm 0.006$ & $18.2 \pm 0.002$ & $13.5 \pm 0.005$ & $23.1 \pm 0.006$ & $10.2 \pm 0.03$ \\
Cholesterol ethers & $20.4 \pm 0.006$ & $8.9 \pm 0.003$ & $10.5 \pm 0.004$ & $8.1 \pm 0.003$ & $26.7 \pm 0.005$ & $5.9 \pm 0.005$ \\
\hline
\end{tabular}

$\mathrm{P} \leq 0.05 ;(M \pm m, n=5)$ from each population. 


\section{DRAHAN et al.}

0.25. A low ratio of cholesterol and phospholipids in the ejaculate may lead to the impairment of permeability of the cellular membranes and destructive and functional changes in sperm which, at the end, leads to the decrease in resistance and reproductive capability of sperm cells $[23,24]$.

As for phospholipids and cholesterol, the concentration of ethers of cholesterol was lower in sperm after cryopreservation as compared to the native sperm. It is especially true for sterlet of the Volga population, where it was $9 \%$ less compared to the native state.

The changes in the ratio of the contents of free and etherized cholesterol were also determined. In the sperm of sterlet of Danube, Dnipro, and Volga populations the proportion between the content of free and etherized cholesterol was 29, 36, and $35 \%$ lower compared to the indices of the control ejaculate. The obtained data demonstrate that the level of etherized cholesterol in the sperm of sterlet of Dnipro and Volga populations was $7 \%$ and $6 \%$ higher respectively as compared to the Danube population.

Our experiment established furthermore that the level of free fatty acids in the sperm of the three populations of sterlet was $11,14.5$, and $25 \%$ lower as compared to the sperm which was not subject to cryopreservation.

It should be noted regarding the determined regularities of the content of free fatty acids that their special composition of cellular membranes of the sperm of sturgeons with prevailing essential shares of unsaturated fatty acids, which are predecessors of eicosanoids (prostagladins, thromboxanes, and leukotrienes) and play the role of bioregulators of many physiological processes in the cell $[15,23]$, impacts the cryoresistance of the cells of these objects and requires principally novel approaches to elaborating more efficient types of cryoprotectors or membrane stabilizers.

It was established during the experiment that the concentration of tryacylglycerol in the fish ejaculate was lower compared to the native sperm of Danube sterlet by $12 \%$, Dnipro sterlet by $13 \%$, and Volga sterlet by $22 \%$.

The obtained results indicate the important role that lipids of the plasmatic membrane of sperm cells may have in the resistance to cooling and the observed changes are in good agreement with the findings of other researchers $[11,13,14]$. It is known that the sensitivity of fish sperm cells to cold shock changes de- pending on time and temperature, absence or presence of cryoprotectants and the type of cryoprotectant. Decisive factors are the stage of maturity of sperm cells and the degree of ejaculate dilution $[2,14,26]$. Further studies of interactions between sperm cells and their environment during cryopreservation, under different temperature conditions and the addition of other cryoprotectants, are instrumental to have a deeper understanding of the ways of preventing or decreasing negative changes, caused by cryopreservation processes.

\section{CONCLUSIONS}

The impact of low temperatures on the lipid composition of reproductive cells of male sterlets (Acipenser ruthenus L.) in a deep-freezing environment leads to substantial changes therein as it does in other fish species. It was established that during the thawing of frozen sperm cells which preserved their viability after deep freezing, their lipid composition and motility were severely impaired.

\section{Вплив кріоконсервації на ліпідний склад репродуктивних клітин самців стерляді (Acipenser ruthenus L.)}

$$
\begin{gathered}
\text { Л. П. Драган }{ }^{1} \text {, С. П. Весельський }{ }^{2} \text {, } \\
\text { Ю. П. Рудь }{ }^{1} \text {, Л. П.Бучацький }{ }^{1,2} \\
\text { e-mail: dragan_1@ukr.net }
\end{gathered}
$$

${ }^{1}$ Інститут рибного господарства НААН, Вул. Обухівська 135, Київ, Україна, 03164

${ }^{2}$ Київський національний університет

ім. Тараса Шевченка, Вул. Володимирська, 60, Київ, Україна, 01033

Мета. Оцінити вплив низьких температур на ліпідний склад репродуктивних клітин самців стерляді (Acipenser ruthenus L.) за присутності кріозахисного середовища. Методи. Визначення якості сперми (колір, консистенцію, концентрацію та рухливість сперматозоїдів) оцінювали загальноприйнятими біохімічними методами та методом світлової мікроскопії 3 застосуванням стандартного обладнання. За допомогою тонкошарової хроматографії в спермі 10 досліджуваних риб з трьох різних річкових регіонів - Дунаю, Дінпра та Волги, було виявлено п'ять фракцій нейтральних ліпі-дів. Всі фракції ліпідів (фосфоліпіди, холестерол, вільні жирні кислоти, триацилгліцерол, та ефіри холестеролу) продемонстрували нижчі середні відсоткові показники (70, 12, 10, 5 та 3 \% відповідно) щодо трьох популяцій стерляді. Також було зафіксовано значне погіршення рухливості (в середньому на 50 \%). Результати. Отримані показники активності сперми стерляді до і після іiі кріоконсервації, свідчать про високу якість 


\section{IMPACT OF CRYOPRESERVATION ON LIPID COMPOSITION OF REPRODUCTIVE CELLS}

нативної сперми і іï суттєве погіршення піс-ля заморожування/розморожування. Висновки. Вплив низьких температур на ліпідний склад репродуктивних клітин самців стерляді (Acipenser ruthenus L.) за присутності кріозахисного середовища призводить до порушення фосфоліпідного бішару їх мембран. Встановлено, що при відтаюванні заморожених сперміїв, які зберегли життєздатність після кріоконсервації, відновлюються в деякій мірі їх рухливість і здатність до запліднення яйцеклітини, при цьому сповільнюється. рухомість сперміїв.

Ключові слова: ліпіди, кріозахисне середовище, кріобанк.

\section{Влияние криоконсервации на липидный состав репродуктивных клеток самцов стерляди (Acipenser ruthenus L.)}

\author{
Л. П. Драган ${ }^{1}$, С. П. Весельский ${ }^{2}$, \\ Ю. П. Рудь ${ }^{1}$, Л. П.Бучацкий ${ }^{1,2}$ \\ e-mail: dragan_1@ukr.net
}

${ }^{1}$ Институт рыбного хозяйства УААН, Ул. Обуховская 135, Киев, Украина, 03164

2 Киевский национальный университет им. Тараса Шевченко, ул. Владимирская, 60, Киев, Украина 01033

Цель. Оценить влияние низких температур на липидный составрепродуктивныхклетоксамцовстерляди(Acipenser ruthenus L.) в присутствии криозащитной среды. Методы. Определение качества спермы (цвет, консистенцию, концентрацию и подвижность сперматозоидов) оценивали общепринятыми биохимическими методами и методом световой микроскопии с применением стандартного оборудования. С помощью тонкослойной хроматографии в сперме 10 исследуемых рыб из трех разных речных регионов - Дуная, Днепра и Волги было обнаружено пять фракций нейтральных липидов. Все фракции липидов (фосфолипиды, холестерол, свободные жирные кислоты, триацилглицерол и эфиры холестерола) продемонстрировали более низкие средние процентные показатели (70, 12, 10, 5 и $3 \%$ соответственно) в трех популяциях стерляди. Также было зафиксировано значительное ухудшение активности (в среднем на 50 \%). Результаты. Полученные показатели активности спермы стерляди до и после ее криоконсервации, свидетельствуют о высоком качестве нативной спермы и ее существенное ухудшение после замораживания/размораживания. Выводы. Влияние низких температур на липидный состав репродуктивных клеток самцов стерляди (Acipenser ruthenus L.) в присутствии криозащитной среды приводит к нарушению фосфолипидного бишара их мембран. Установлено, что при оттаиваниии замороженных сперматозоидов, которые сохранили жизне- способность после криоконсервации, восстанавливаются в некоторой степени их подвижность и способность к оплодотворению яйцеклетки, при этом замедляется подвижность сперматозоидов.

Ключевые слова: липиды, криозащитная среда, криобанк.

\section{REFERENCES}

1. Ponomareva EN, Krasilnikova AA, Tikhomirov AM, Firsova $A V$. New Biotechnological methods for cryopreservation of reproductive cells. Ecology, Development, 2016;11(1):59-68. doi: 10.18470/1992-10982016-1-59-68.

2. Belaya MM, Tikhomirov AM. Scientific methodological recommendations on preserving biological diversity of southern seas of the RF using modern methods of cryopreservation of reproductive cells. Rostov-on-Don, Southern Scientific Center RAS Publ., 2013:14 p.

3. Kostetsky EYa, Boroda AV, Odintsova NA. Changes in lipid composition of embryonal cells of mussels Mytilus trossulus in the process of cryopreservation. Biophysics, 2008;53(4):658-65.

4. Pat. 6417 Ukraine, MKB 7 F25 D 3/10. A device for cryopreservation of biological objects of animal and plant origin. L.V. Horbunov, V.I. Kabachny, N.I. Horbunova, M.V. Hrynzhevsky. Publish. on May 16, 2005. Bul. No.5.

5. Hojnacki JL, Smith SC. Separation of six lipid clas-es on one thin-layer chromatogram. J. Chromat., 1974; 90(2):364-7.

6. Maksymenko VB. Quantitative thin-layer chromatography of lipids and ethers of cholesterol. Laboratornoe delo, 1983;(12):17-8.

7. Folch J, Less M, Sloan Stanley GH. A simple method for the isolation of total lipids from animal tissues. J. Biol. Chem., 1957;226(1):497-509.

8. Lowry OH, Rosebrough NJ, Farr AL, Randall RJ. Protein measurement with the Folin Phenol reagent. J. Biol. Chem., 1951;193(1):265-75.

9. Vlizlo VV, Fedoruk RS, Ratych IB. et al. Laboratory methods of investigation in biology, stockbreeding and veterinary. Reference book. Lviv, SPOLOM, 2012:764 p.

10. Maksymjuk AV, Vorobets ZD. Mechanism of sperm adaptation to cryopreservation conditions. Khimia i biologia: electronic scientific journal. 2014;7(7). URL: $\mathrm{http} / / / 7$ universum.com/ru/nature/archive/item/1430

11. Odintsova N.A., Boroda A.V., Velansky P.V., Kostetsky E.Ya. The fatty acid profile changes in marine invertebrate larval cells during cryopreservation. Cryobyology. 2009; 59:335-43.

12. Mandal R, Badyakar D, Chakrabarty J. Role of membrane lipid fatty acids in sperm cryopreservation. Adv. Androl., 2014. doi: 10.1155/2014/190542.

13. Kuznetsov VI, Morrison VV, Lisko OB, Tsareva TD, Sretenskaya DA, Gavrilova IB, Hiebozharova OA. Lipids 


\section{DRAHAN et al.}

in the structure and functions of biological membranes. Saratov J. Med. Sci. Res., 2014;10(2):262-6.

14. Blesbois E, Grasseau I, Seigneurin F. Membrane fluidity and the ability of domestic bird spermatozoa to survive cryopreservation. Reproduction, 2005;129(3):371-8.

15. Kundenko NP, Kundenko ON, Shinkarenko IN. The control system parameters of biological objects after processing low-intensity acoustic field in the process of cryopreservation. Engineering of nature management, 2016;1(5):74-9.

16. Pugovkin AYu, Kopeika EF, Nardid OA, Cherkashina $\mathrm{YaO}$. Investigation of permeability of carp spermatozoa membranes for water molecules. Biophysics, 2014; 59(3):481-7.

17. Kopeika EF. Ecological Niche as the Factor Determining Cryoresistance in Fish Spermatozoa. Probl. Cryobiol. Cryomed., 2014;24(4):302-11.

18. Burchanova A.G. Zabalueva YuYu, Ivanov AYu, Polozova $T V$. Investigation of fatty acid composition of the proteinfatty emulsion from salmon milt. International scientific journal, 2016;11(53):28-30.

19. Travis AJ, Kopf GS. The role of cholesterol efflux in regulating the fertilization potential of mammalian spermatozoa. J. Clin. Invest., 2002;110(6):731-6. doi: 10.1172/JCI16392.

20. Ozolina NV, Hurina VV, Nesterkina IS, Dudareva LV, Katyshev VN, Nurminsky VN. Fatty acid composition of total lipids of vacuolar membrane under abiotic stress.
Biologicheskie membrany: zhurnal membrannoi i kletochnoi biologii, 2017;34(1):63-9.

21. Moce E, Tomas C, Blanch E, Graham JK. Effect of cholesterol-loaded cyclodextrins on bull and goat sperm processed with fast or slow cryopreservation protocols. Animal., 2014;8(5):771-6. doi: 10.1017/ S1751731114000226.

22. Lima de Souza W, Moraes EA, Costa JM, Graham JK. Cholesterol-loaded cyclodextrin in fresh goat sperm improves cryosurvival rates. R. bras. Ci. Vet., 2016;23(12):93-8. doi.org/10.4322/rbcv.2016.037.

23. Lee YS, Lee S, Lee SH, Yang BK, Park CK. Effect of cholesterol-loaded-cyclodextrin on sperm viability and acrosome reaction in boar semen cryopreservation. Anim. Reprod. Sci., 2015;159:124-30. doi: 10.1016/j. anireprosci.2015.06.006.

24. Ozolina NV, Nesterkina IS, Dudareva LV, Nurminsky $V N$, Gurina VV. Changes in Composition of Vacuolar Membrane Lipid Fatty Acids Under Osmotic Stress. J. Stress Physiol. Biochem., 2016;12(1):31-41.

25. Los DA, Mironov KS, Allakhverdiev SI. Regulatory role of membrane fluidity in gene expression and physiological functions. Photosynth. Res., 2013;116(2-3):489-509. doi: 10.1007/s11120-013-9823-4.

26. Moraes EA, Matos WCG, Graham JK; Ferrari Junior $W D$. Cholestanol-loaded-cyclodextrin improves the quality of stallion spermatozoa after cryopreservation. Anim. Reprod. Sci., 2015;158:19-24. doi: 10.1016/j. anireprosci.2015.04.004. 